\title{
A congenital soft tissue Ewing sarcoma in a newborn patient
}

\author{
Mustafa Akçalı ${ }^{1}$, Hacer Yapıcıoğlu${ }^{1}$, Eray Akay ${ }^{1}$, Ferda Özlü ${ }^{1}$, Banu Kozanoğlu ${ }^{2}$, Kıvılcım \\ Erdoğan $^{3}$, Gülfiliz Gönlüşen ${ }^{3}$, Mehmet Satar ${ }^{1}$ \\ Divisions of ${ }^{1}$ Neonatology and ${ }^{2}$ Pediatric Oncology, Department of Pediatrics, and ${ }^{3}$ Department of Pathology, Çukurova \\ University Faculty of Medicine, Adana, Turkey, E-mail: hyapicioglu@cu.edu.tr \\ Received: 4th August 2016, Revised 26th September 2016, Accepted: 13th October 2016
}

\begin{abstract}
SUMMARY: Akçalı M, Yapıcıoğlu H, Akay E, Özlü F, Kozanoğlu B, Erdoğan K, Gönlüşen G, Satar M. A congenital soft tissue Ewing sarcoma in a newborn patient. Turk J Pediatr 2017; 59: 76-79.

Congenital Ewing sarcoma is extremely rare. Here we present a newborn baby born with a mass on the left shoulder. Immunohistochemical staining showed congenital Ewing sarcoma. Chemotherapy and then surgical operation were planned, however the patient died before initiation of chemotherapy on the 30th day of life.
\end{abstract}

Key words: congenital Ewing sarcoma, soft tissue.

Ewing sarcoma family of tumors (ESFT) term is generally used for the tumor group with undifferentiated small round cells probably originated from stem and/or progenitor cells of mesoderm and neural crest lineages and are usually related with the classic chromosomal translocations $\mathrm{t}(11 ; 22)$ (q24;q12) in approximately $85-90 \%$ of Ewing sarcoma (ES) cases $^{1-3}$. In this group, peripheral primitive neuroectodermal tumor is found besides bone and soft tissue ESs.

Ewing sarcoma is the second most common tumor of bone in childhood and adolescents after osteosarcoma, peak incidence is 10 to 15 years of age. $30 \%$ of cases are seen in children under 10 years of age ${ }^{4}$. Congenital ESFT develops in various parts of the body, however the most frequent sites are extremities. Only $4 \%$ of ES is in soft tissues ${ }^{5}$. The most common symptoms are local swelling and pain.

Ewing sarcoma is characterized by small, undifferentiated blue cells with hyperchromatic nuclei and scanty cytoplasm. Immunohistochemical staining is used for differentiation of ES and tumors with small round cells such as lymphoma, rhabdomyosarcoma and neuroblastoma. Immunohistochemical finding such as CD99 reactivity is characteristic ${ }^{5}, 6$. There is no standard chemotherapy for congenital ESFT yet.

Congenital ES is a rare entity and it has a poor prognosis. To our knowledge there are less than
30 cases in the literature. In this case report, we reported a soft tissue congenital ES on the left shoulder of a newborn baby.

\section{Case Report}

The female patient was born at 36th gestational week via normal vaginal delivery and admitted to NICU for respiratory distress and a mass on her left shoulder. She was referred to our hospital on 10th day of life for further evaluation as the mass was enlarged. The Syrian parents were consanguineous. Physical examination revealed weight 3,060 g (50-90 p), length $48 \mathrm{~cm}(50-90 \mathrm{p})$ head circumference $32 \mathrm{~cm}(10-50 \mathrm{p})$, respiratory rate $58 / \mathrm{min}$, she had intercostal retractions; other findings were normal. There was a $10 \times 9 \mathrm{~cm}$ mass which had hemorrhagic and necrotic areas on it. $\mathrm{X}$-ray showed no bone metastasis in humerus (Figs. 1a, b). Laboratory tests were as follows: hemoglobin $10.7 \mathrm{~g} / \mathrm{dl}$, hematocrit $32.1 \%$, leucocyte count $16,940 / \mathrm{mm}^{3}$, thrombocyte $306,000 / \mathrm{mm}^{3}$, procalcitonin $3.18 \mathrm{ng} / \mathrm{ml}(0-0.5)$, blood smear and biochemical tests were normal. Ampicillin and gentamycin treatment were started. Blood culture was negative. During hospitalization, she had fever occasionally. She was not fed enterally and total parenteral nutrition was started. Albumin level was 2.1 $\mathrm{g} / \mathrm{dl}$ in the following days and albumin was infused.

Magnetic resonance imaging of the lesion 
with contrast agent showed a $11 \times 7 \times 8 \mathrm{~cm}$ heterogeneous soft mass with a heterogeneous contrast uptake. Abdominal ultrasonography and echocardiography were normal. Biopsy of the mass showed tumor cells with a scanty cytoplasm and hyperchromatic nucleus (Fig. 2). Immunohistochemical markers which included CD99, SMA, desmin, myogenin, LCA, Tdt, Pax5, and myeloperoxidase were reviewed: CD99 was positive (Fig. 3); SMA, desmin, myogenin, LCA, Tdt, Pax5, and myeloperoxidase were negative. Congenital Ewing sarcoma was diagnosed and neoadjuvant chemotherapy (vincristine, topotecan, cyclophosphamide and mesna) was planned. However, she had renal insufficiency [blood urea nitrogen $84 \mathrm{mg} / \mathrm{dl}$, creatinine $1.38 \mathrm{mg} / \mathrm{dl}$, uric acid $10.4 \mathrm{mg} / \mathrm{dl}$, phosphate
$2.1 \mathrm{mg} / \mathrm{dl}$, LDH 2,375 U/L (100-190)] and anemia (hematocrit 23\%). She was intubated for respiratory insufficiency and unfortunately the patient died on the 30th day of life before chemotherapy.

\section{Discussion}

Ewing sarcoma is especially rare in infants and newborns. In a case series of 734 ES patients, only 19 patients $(2.6 \%)$ were younger than 3 years of age $\mathrm{e}^{7}$. To our knowledge there are less than 30 newborn patients with ES ${ }^{8-12}$.

Ewing sarcoma is rare in African-American race compared to Caucasian race. Although it is more common in males in toddlers, there is a female predominance in the newborn period 7,13 . The present case was also a female patient.

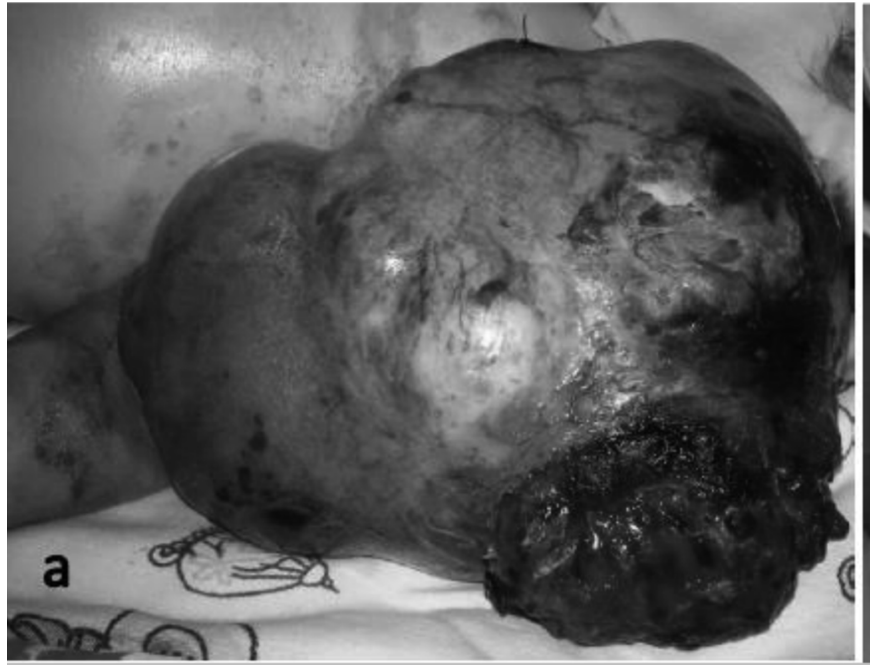

Fig. 1a. Soft tissue mass on the left shoulder.

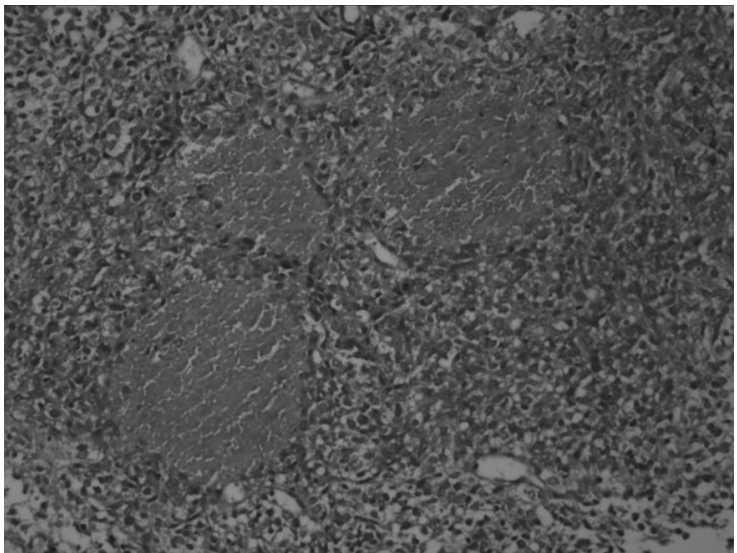

Fig.2. Tumor cells with a scanty cytoplasm and hyperchromatic nucleus with hemorrhagic areas (red areas, hematoxylin and eosin staining, x200).

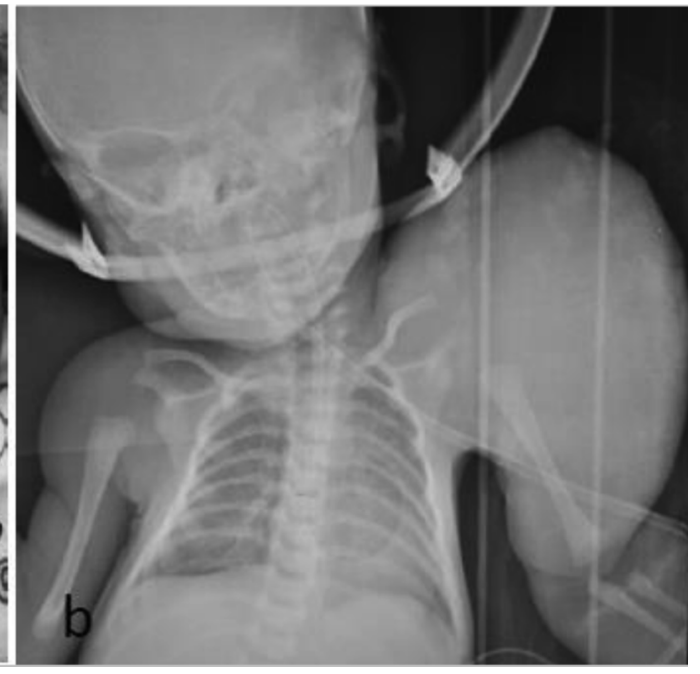

Fig.1b. X-ray of left humerus.

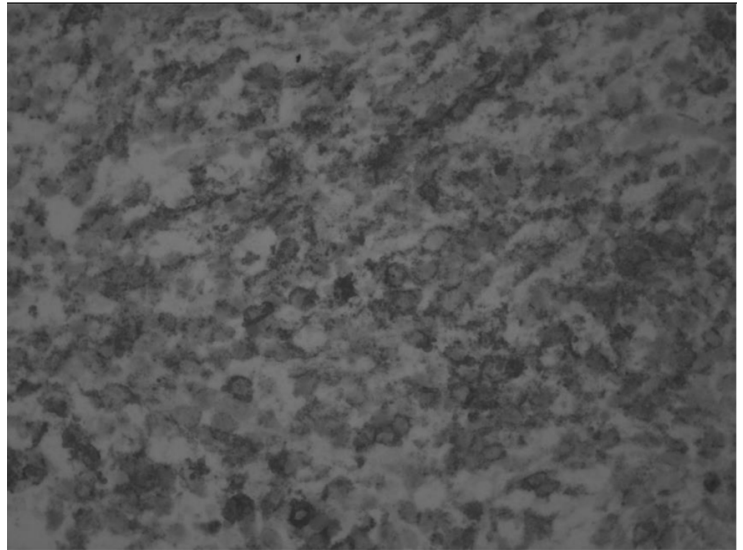

Fig. 3. All cells are tumor cells with positive CD 99 . 
Cytogenetic and molecular studies are important for the diagnosis. Ewing sarcoma is characterized with undifferentiated blue cells with a scanty cytoplasm and hyperchromatic nucleus. Brisk mitoses are observed 6,14 . Immunohistobiochemical staining is used for differentiation of ES from tumors with blue, round cell tumors such as lymphoma, rhabdomyosarcoma and neuroblastoma. Muscle related markers (such as desmin and actin) are negative in ES. CD99 staining is usually positive. Translocation $(11 ; 22)$ and its variant is specific for ESFT and found in most patients $5,6,15$. Unfortunately we have not investigated the translocation $(11 ; 22)$, however CD99 was positive in favor of ES. SMA, desmin, myogenin, LCA, Tdt, Pax 5 and myeloperoxidase were negative.

Treatment for ESFT consists of radical surgical resection of the tumor either without chemotherapy or after chemotherapy. However, there has been no standard treatment modality yet $5,6,14$. High dose chemotherapy, radiotherapy of localized tumors and autologous stem cell grafting have been used in the treatment ${ }^{15,16}$. Systemic chemotherapy and local control measures improved survival of patients with localized tumors to more than $70 \%{ }^{17}$. However, survival rate is low in newborn babies. Up to 2008, 21 congenital ESFT cases were reported and only $5 \%(1 / 21)$ had the chance of long term survival ${ }^{15}$. In another report by Pan et al. ${ }^{9}, 13$ congenital ES cases were evaluated. Eight of the patients died after 16 months and the mortality rate was high (5/8 patients) in the cases with metastasis and in female patients (mortality rate $71 \%$ in females and $50 \%$ in males) although metastasis rate was higher in boys (67\% vs. $33 \%)$. Serum LDH has been reported to have clinical value in predicting course of the disease ${ }^{18}$. In Priya et al.'s ${ }^{18}$ study in children with ESFT, the value of $\mathrm{LDH}$ ranged from $142 \mathrm{U} / \mathrm{L}$ to 1,965 $\mathrm{U} / \mathrm{L}$ with a median of $363 \mathrm{U} / \mathrm{L}$ and $75 \%$ of cases with values above this median level had metastasis. Chest CT scan to evaluate pulmonary metastasis and radionuclide bone scan to evaluate the entire skeleton for multiple metastasis is recommended. In our patient, LDH was very high, we could not perform further evaluation for metastasis; however, there was no abnormality on chest X-ray and abdominal ultrasonography. We planned neoadjuvant chemotherapy and then resection of the tumor, unfortunately she died before the first dose of chemotherapy.

In conclusion, ES is an aggressive tumor and extremely rare in newborn babies and infants. Standard therapy in newborns is based on the therapy in children and adults. Ewing sarcoma should be in mind in newborns with soft tissue mass.

\section{REFERENCES}

1. Meltzer PS. Is Ewing sarcoma a stem cell tumor? Cell Stem Cell 2007; 1: 13-15.

2. Riggi N, Suva ML, Stamenkovic I. Ewing's sarcoma origin: From duel to duality. Expert Rev Anticancer Ther 2009; 9: 1025-1030.

3. Lawlor ER, Sorensen PH. Twenty years on-what do we really know about Ewing sarcoma and what is the path forward? Crit Rev Oncog 2015; 20: 155-171.

4. Glass AG, Fraumeni JF Jr. Epidemiology of bone cancer in children. J Natl Cancer Inst 1970; 44: 187-199.

5. Coffin CM, Dehner LP. Neurogenic tumors of soft tissue. In: Coffin CM, Dehner LP, O'Shea PA (eds). Pediatric Soft Tissue Tumors. Baltimore: Lippincott, Williams and Wilkins; 1997: 108-116.

6. Bernstein M, Kovar H, Paulussen M. Ewing sarcoma family of tumors: Ewing sarcoma of bone and soft tissue and the primitive neuroectodermal tumors. In: Pizzo PA, Poplack DG (eds). Principles and Practice of Pediatric Oncology (5th ed). Philadelphia: Lippincott, Williams and Wilkins; 2006: 1002-1032.

7. Maygarden SJ, Askin FB, Siegal GP, et al. Ewing's sarcoma of bone in infants and toddlers. A clinicopathologic report from the Intergroup Ewing's study. Cancer 1993; 71: 2109-2118.

8. Saito Y, Matsuzaki A, Suminoe A, et al. Congenital Ewing sarcoma in retroperitoneum with multiple metastases. Pediatr Blood Cancer 2008; 51: 698-701.

9. Pan SP, Park SH, Wang KC, et al. Congenital paraspinal Ewing sarcoma family of tumors with an epidural extension. J Clin Neuroscience 2010; 17: 1599-1601.

10. Krenova Z, Kren L, Blatny J, et al. Extraosseal Ewing sarcoma as a rare cause of the blueberry muffin baby syndrome: A case report and the review of the literature. Am J Dermatopathol 2011; 33: 733-735.

11. Okpokowuruk FS, Oloyede I. Congenital Ewing's sarcoma in a neonate in Uyo--a case report. Pan Afr Med J 2013; 15: 90.

12. Jin SG, Jiang XP, Zhong L. Congenital Ewing sarcoma/ peripheral primitive neuroectodermal tumor. A case report and review of the literature. Pediatr Neonatol 2016; 57: 436-439.

13. Wilkins RM, Pritchard DJ, Omer Burgert E, Unni KK. Ewing's sarcoma of bone: Experience with 140 patients. Cancer 1986; 58: 2551-2555. 
14. Carvajal R, Meyers P. Ewing's sarcoma and primitive neuroectodermal family of tumors. Hematol Oncol Clin North Am 2005; 19: 501-525.

15. Kim SY, Tsokos M, Helman LJ. Dilemmas associated with congenital Ewing sarcoma family tumors. J Pediatr Hematol Oncol 2008; 30: 4-7.

16. van der Berg H, Dirksen U, Ranft A, Jürgens H. Ewing tumors in infants. Pediatr Blood Cancer 2008; 50: 761-764.
17. Womer RB, West DC, Krailo MD, et al. Randomized controlled trial of interval-compressed chemotherapy for the treatment of localized Ewing sarcoma: A report from the Children's Oncology Group. J Clin Oncol 2012; 30: 4148-4154.

18. Priya D, Rekha VK, Appaji L, Aruna KBS, Padma M, Kumari P. Histological diversity and clinical characteristics of Ewing sarcoma family of tumors in children: A series from a tertiary care center in South India. Indian J Cancer 2015; 52: 331-335. 